\title{
Study on Metabolic Compounds of Gracilaria salicornia against Anti-Inflammatory Activity
}

\section{Ranganayaki Paramsivam ${ }^{1}$, Susmitha Sudevan ${ }^{1}$, Shalini Sundar ${ }^{1}$, and VijayaraghavanRamasamy ${ }^{2} *$}

${ }^{1}$ Dept. of Microbiology, Nehru Arts and Science College, T.M.Palayam, Coimbatore, Tamil Nadu, India

${ }^{2}$ PSG Centre for Molecular Medicine and Therapeutics, PSG Institute of Medical Sciences and Research, Coimbatore, India

*Corresponding author

\section{A B S T R A C T}

\section{Keywords}

Gracilaria salicornia, Phytochemicals, TLC and Antiinflammatory.

\section{Article Info}

Accepted:

15 March 2016 Available Online: 10 April 2016
This study investigated the medicinal value of red algae Gracilaria salicornia, arich source of bioactive compounds. The algal aqueous extract was analyzed for anti-bacterial and minimum inhibitory concentration against pathogens. The phytochemical analysis shows the presence of Alkaloids, Saponin, Phenols, Steroids, Proteins, Tannins, Flavonoids, Amino acids and absence of Terpenoids, Anthraquinone. The chromatographical analysis reveals the presence of possible metabolites. The purified active compounds through TLC and crude extract are subject to analyze the in vitro and anti-inflammatory activity and the crude algal extract was subjected for the in vivo anti- inflammatory activity. It was observed that the algal extract have the relatively active against inflammation.

\section{Introduction}

Inflammation is the normal physiological and immune response to tissue injury and occurs when the human body attempt to counteract potentially injurious agents, such as invading microbes. This biological process involve the innate and immune systems, and is often initiated by migration of immune cells from blood vessels and release of mediator, followed by recruitment of inflammatory cells and proinflammatory cytokines to eliminate foreign pathogens, all of which function to eliminate infection and repair injured tissues. Among the different types of immune cells, play an important role in triggering inflammation during pathological conditions by overproducing inflammatory mediators through upregulation of inducible genes that contribute to inflammatory responses, including endotoxin mediated septic shock, 
rheumatoid arthritis, asthma and other inflammatory vascular disease. Although the main function of inflammation is beneficial to host defense, aberrant resolution and prolonged inflammation can result in various chronic disorders. Over the past few decades, many studies have demonstrated that chronic inflammation is a linked to a wide range of progressive diseases, including cancer, obesity, aging, diabetes, neurological diseases, metabolic disorder, and cardiovascular diseases. A large numbers of anti-inflammatory drugs are currently being used to ameliorate pain and inflammatory diseases.

Marine algae, Gracilaria salicornia, synonymously known as red algae. They are a rich source of natural bioactive products, although a little has been done to define an ecological role for these compounds. The use of marine natural products able to produced agar in many countries and inhibit bacteria development offers a rich pharmaceutical formulations, cosmetics and industrial applications. In fact one of the earliest written record from China dating to 600 BC mentions algae a being a food suitable for a king. In Chinese medicine red marine algae have been looked upon as allowing the flow of energy by removing obstruction to this flow caused by wetness and heat. Numerous reports show that Aqueous extract of Gracilaria salicornia present a broad range of biological activities from agar producing industry was evaluated for antimicrobial activity, minimal inhibitory concentration against human pathogens and anti-inflammatory. The ability of seaweeds to produce secondary metabolites of antimicrobial value, such volatile components as phenols, terpenoids, proteins, vitamins, steroids, flavonoids, lipids, and mineral etc., anti-inflammatory value such as retinol which inhibited the hyaluronidase inhibition assay has already been studied.

\section{Materials and Methods}

\section{Collection of Sample and Extraction}

The marine algae Gracilaria salicornia was collected from Pudukkottai District. The sample was identified by Scientist in charge, at the Centre for Marine and Fisheries Research Institution (CMFRI), Mandapam. The collected algae was stored in shade provision in the laboratory for further analysis. The thalli of Gracilaria salicornia were cut into pieces, shade dried and powdered in a grinder to 40-mesh size powder. The extraction was obtained by double distilled water. The extraction was filtered through Whatman No.1 filter paper to obtain a particle free extract. The residue was re-extracted twice and filtered (to elute/collect the excess suspended molecules). Aqueous extracts were pooled, concentrated and freeze dried at $-20^{\circ} \mathrm{C}$ and the dried extract was used for exploring its further potential activity.

\section{Phytochemical Screening}

Phytochemical screening of extracts was carried out according to the standard methods as described by Trease and Evans (1996) for Terpenoids, alkaloids, tannins, flavonoids, steroids, saponins, Reducing sugar, Phenols, Anthraquinines and cardiac glycoside.

\section{Antibacterial Activity}

Antibacterial activity of aqueous extracts was determined against pathogens by agar Diffusion method (Bauer et al., 1966) the agar media was poured into the petri plate. After solidification, a well was prepared in the plates. For qualitative antibacterial analysis, corresponding bacterium are cultured on the LB agar plates and analyzed for zone of inhibition. Briefly the bacterial 
suspension of $0.1 \mathrm{ml}$ was first poured and spread onto the agar plates. The plates were kept for 5-10 minute so that bacteria get sufficient time to adhere on the surface of agar plates. Suitable well cutter was used to make the well on the agar plate. The extracts were seeded into the well. The bacteria were then incubated at $37^{\circ} \mathrm{C}$ for 24 hour and the bacterial inhibition zone for extracts on the plate was visually inspected. Calculations for inner and outer diameters along with diameter differences were measured.

\section{Minimum Inhibitory Concentration}

To determine Minimum Inhibitory Concentration (MIC) $1 \mathrm{ml}$ of nutrient broth was taken in 5 test tubes. Different sets were prepared for each bacterium. Different concentrations of algal extracts ranging from $1 \mathrm{mg}$ to $5 \mathrm{mg} / \mathrm{ml}$ were added into test tubes. To this $50 \mu 1$ of an overnight broth culture of each bacterium were inoculated in the respective tubes and the tubes were incubated for 24 hours at $37^{\circ} \mathrm{C}$. One tube was inoculated with $1 \mathrm{ml}$ sterile nutrient broth with the $50 \mu \mathrm{l}$ of an overnight broth culture of each bacterium and placed at $+4^{\circ} \mathrm{C}$ in a refrigerator overnight to be used as standard for the determination of complete inhibition. MIC is expressed as the lowest dilution, which inhibited growth judged by lack of turbidity in the tube. Because very faint turbidity may be given by the inoculum itself, the inoculated tube kept in the refrigerator overnight may be used as the standard for the determination of complete inhibition.

\section{Thin Layer Chromatography}

\section{Preparation of Chroma Plate}

The glass slides were cleaned and dried in hot air oven. Slurry was prepared by mixing silica gel with double the volume of distilled water in a clean beaker. One drop of slurry was placed on the slide by using another slide edge, the drop of slurry was scattered all over to make thin film. The slides were kept as such for few minutes. Then the chromo plates were activated by heating in hot air oven at $120^{\circ} \mathrm{C}$ for $30 \mathrm{~min}$.

\section{Loading of Sample}

The slides were allowed to cool at room temperature and marked about $2 \mathrm{~cm}$ from the bottom as the origin. The working suspensions were loaded at the center of the each slide above from the edge.

\section{Development of Chromatogram}

The development tank was saturated with suitable solvent systems according to Eskil Hultin (1966).

Alkaloids : Benzene/ Methanol-80:20

Flavonoids : Chloroform/Methanol-70:30

Lipid

Chloroform/Methanol/water-10:10:3

Triterpeniods : Acetic acid/water1:3 5

Aminoacids : Butanol/Acetic acid/Water$4: 1: 1$

The slides were kept in the tank without touching baseline by solvent. The final solvent front was marked and the slides were dried.

\section{Spot Visualization}

For visualization of Flavonoids $1 \%$ ethanolic solution of Aluminum chloride was used and viewed under 560nm UV light. Alkaloids and Triterpenoids were visualized under UV light and they were 
visible as yellow and orange fluorescent spots. Few pieces of iodine crystals were kept in the tank and covered with glass plate to saturate the tank with iodine vapor for detecting lipids. The plate was then kept in iodine vapor saturated tank and left for few hours and brown colored spots were visualized. For amino acids ninhydrin was sprayed on the plate and observed for purple color spots.

\section{Retrieval of the Active Compound}

Spots on the preparative silica gel slides were scratched with the help of clean and dry spatula and collected in beaker containing appropriate solvents (Bishnu Joshi, 2011) and left overnight. The content in the beaker was stirred and filtrated through Whattman no. 1 filter paper. The filtrate was collected in clean and dry beaker. The filtrate containing active compound was used for the determination of antimicrobial effect against in vitro analysis of Anti-inflammatory activity.

\section{In-vitro Anti-inflammatory Activity by Hyaluronidase Inhibition Assay}

3-5 U hyaluronidase in $100 \mu \mathrm{l}$ in $20 \mathrm{mM}$ sodium phosphate buffer ( $\mathrm{pH} 7)$ with $77 \mathrm{mM}$ $\mathrm{NaCl} 2,0.1 \%$ BSA was pre-incubated with different concentration of the active compound and aqueous extract Gracilaria salicornia of for $15 \mathrm{mins}$ at $37^{\circ} \mathrm{C}$. Assay was commenced by adding $100 \mu \mathrm{l}$ hyaluronic acid $(0.03 \%$ in $300 \mathrm{mM}$ Sodium Phosphate $(\mathrm{pH} 5.35)$, to the incubation mixture and incubated for further $45 \mathrm{mins}$ at $37^{\circ} \mathrm{C}$. The undigested hyaluronic acid was precipitated with a $1 \mathrm{ml}$ of acid albumin solution made up of $0.1 \%$ BSA in $24 \mathrm{mM}$ Sodium acetate and $79 \mathrm{mM}$ acetic acid (pH3.75). The mixture was kept at room temperature for 10 mins and the absorbance of the reaction mixture was measured at $600 \mathrm{~nm}$ in Colorimeter.
Absorbance in the absence of enzyme was used as reference value of maximum of inhibition. Inhibitory activity of test compound versus absorbance in the absence of the enzyme was used for calculation. Indomethocine was used as reference standard by Ling et al., 2003 and Sigma protocol.

\section{In vivo Anti-inflammatory Activity by Paw Edema Method}

In the present study, anti-inflammatory activity was determined in Wistar rats according to the method described by Vasudevan et al., 2006.

Male Wistar rats were divided into 4 groups of six each.

Group I and II served as control and received distilled water $10 \mathrm{ml} / \mathrm{kg}$

Group III served as standard and treated with Indomethiocin $10 \mathrm{mg} / \mathrm{kg}$

Group IV was treated with aqueous extract of Gracilaria salicornia 200mg/kg.

The animals were pretreated with the drug 1 hour before the administration of carrageenan. The thickness $(\mathrm{mm})$ of the paw was measured immediately and at $30,60,90,120,150,180,210 \& 240$ min interval after the carrageenan injection, by using Vernier caliper.

The percent protection of volume for each group was calculated as:

$$
\begin{aligned}
& \% \text { protection of paw volume }=\frac{(\mathrm{Vt}-\mathrm{Vo})_{\text {Control }}-(\mathrm{Vt}-\mathrm{Vo})_{\text {Treated }}}{(\mathrm{Vt}-\mathrm{Vo})_{\text {Control }}} \mathrm{X} 100 \\
& \mathrm{Vt}=\text { paw volume after carrageenan } \\
& \text { administration. }
\end{aligned}
$$


Vo $=$ paw volume before carrageenan administration.

The percentage of inhibition was carried out for every $30 \mathrm{~min}$ interval.

\section{Statistical Analysis}

The results were expressed as means \pm S.D. of independent experiments. Data were analyzed by an analysis of variance $(\mathrm{P}<0.05)$ and the means separated by one-way ANOVA test and its considered significant.

\section{Results and Discussion}

\section{Phytochemical Screening}

Phytochemical screening study of Gracilaria salicornia extract revealed that the extract had significant quantity Alkaloids, Phenols. Steriods, Protein, Amino acids, Flavonoids, Tannins and absence of Terpenoids, Anthraquinone, Saponin, Phytosterols, Reducing sugars and Sugars (Table 1).

\section{Antibacterial Activity}

Preliminary Antibacterial activity screening was reported to the algal sample. 20 and 40 $\mu \mathrm{l}$ of the working suspension/solution of algal extract Gracilaria salicornia and same volume of distilled water for control were filled in the wells with the help of micropipette. After incubation, the plates were observed for the zone of inhibition [ZI](Fig:1), the diameter of the inhibition zone were measured and recorded (Table:2).

\section{Minimum Inhibitory Concentration}

Secondary screening of Gracilaria salicornia against pathogens revealed the minimum inhibitory concentration of algal extract. The result was tabulated in table 3 .

\section{Separation of Active Compound from Thin Layer Chromatography (TLC)}

The chromatographic observation revealed the presence of amino acids, alkaloid, flavonoids, lipids and triterpenoids. The result for the thin layer chromatography.Fig:2, Table:4 represented the aqueous extract contain amino acids, alkaloids, flavonoids, lipids and triterpenoids in the $\mathrm{R} f$ value.

\section{In vitro Anti-inflammatory Activity by Hyaluronidase Inhibition Assay}

The reduction levels of Hyaluronidase enzyme in in-vitro studies were observed. The maximum inhibition was found in the crude extractfollowed by in and amino acids, triterpenoids, alkaloids, and flavonoids were observed and tabulated in table 5.

\section{In vivo Anti-inflammatory Activity by Percentage Inhibition of Paw Edema}

The percentage inhibition of paw edema was calculated for a control, a standard drug of Indomethiocin and algal extracts Gracilaria salicornia. The paw volume after the administration of carrageenan was measured at each 30 minutes and the reduction in paw thickness was noted. The results show that the effectively controlled the paw thickness of Wister rats at the end of each 30 minutes. These results were comparable with that of control and the maximum percentage of inhibition of paw thickness was found at 60 minutes in Gracilaria salicornia $(77.53 \%)$ of carrageenan injection. The result was tabulated in table 6 .

Marine algae are rich in poly unsaturated fatty acids (PUFA) and are of potential value as source of essential fatty acids, important in the human beings and animals. 
Table.1 Phytochemical Analysis of Gracilaria salicornia

\begin{tabular}{|c|c|}
\hline Phytochemical Constituents & Observation \\
\hline Alkaloids & - \\
\hline Saponin & + \\
\hline Tannins & - \\
\hline Anthraquinone & + \\
\hline Flavonoids & + \\
\hline Phenols & + \\
\hline Steroids & - \\
\hline Terpenoids & - \\
\hline Phytosterols & + \\
\hline Proteins & + \\
\hline Amino acid & - \\
\hline Sugar & - \\
\hline Reducing sugar & \\
\hline
\end{tabular}

Tabe.2 Antibacterial Activity of Gracilaria salicornia

\begin{tabular}{|l|c|c|}
\hline \multirow{2}{*}{ Test Organisms } & \multicolumn{2}{|c|}{ Zone of inhibition (in diameter-mm) } \\
\cline { 2 - 3 } & $\mathbf{2 0 \mu \mathbf { l }}$ & $\mathbf{4 0 \mu l}$ \\
\hline Salmonella typhi & 0.3 & 0.9 \\
\hline Bacillus & 0.1 & 0.6 \\
\hline E. coli & 0.2 & 0.8 \\
\hline Enterococci & 0.2 & 0.8 \\
\hline Staphylococcus aureus & 0.2 & 0.7 \\
\hline Proteus & 0.5 & 1.2 \\
\hline Pseudomonas & 0.7 & 1.5 \\
\hline Actinomycetes & 0.3 & 0.9 \\
\hline Streptococcus pyogens & 0.6 & 1.3 \\
\hline Candida albicans & 0.5 & 1.1 \\
\hline
\end{tabular}

Table.3 MIC Assay of Gracilaria salicornia

\begin{tabular}{|l|c|c|}
\hline \multirow{2}{*}{ Test Organisms } & \multicolumn{2}{|c|}{ Minimal inhibitory concentration at O.D-540 nm } \\
\cline { 2 - 3 } & $\mathbf{2 0} \mathbf{m g}$ & $\mathbf{4 0 m}$ \\
\hline Salmonella typhi & 0.45 & 0.68 \\
\hline Bacillus & 0.24 & 0.56 \\
\hline E. coli & 0.58 & 0.79 \\
\hline Enterococci & 0.31 & 0.65 \\
\hline Staphylococcus aureus & 0.46 & 0.85 \\
\hline Proteus & 0.47 & 0.87 \\
\hline Pseudomonas & 0.86 & 1.21 \\
\hline Actinomycetes & 0.92 & 1.81 \\
\hline Streptococcus pyogens & 0.41 & 0.55 \\
\hline Candida albicans & 0.89 & 1.48 \\
\hline
\end{tabular}


Table.4 Rf Values of Phytochemical of Gracilaria salicornia

\begin{tabular}{|c|c|}
\hline $\begin{array}{c}\text { Phytochemical } \\
\text { constituents }\end{array}$ & $\boldsymbol{R}$ fvalue \\
\hline Alkaloids & 0.19 \\
\hline Lipids & 0.16 \\
\hline Amino acids & 0.76 \\
\hline Flavonoids & 0.65 \\
\hline Triterpenoids & 0.23 \\
\hline
\end{tabular}

Fig.1 Effective Antimicrobial Activity of Gracilaria salicornia

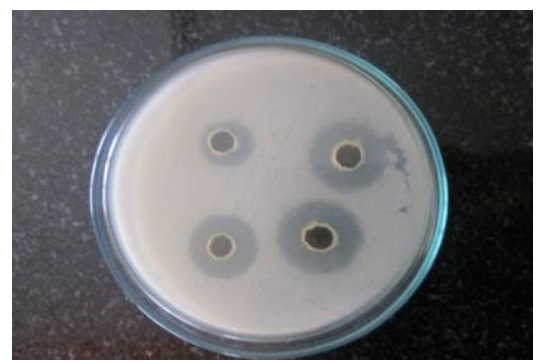

Salmonella typhi

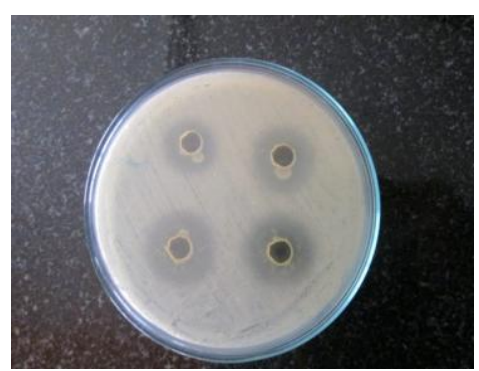

Streptococcus pyogens

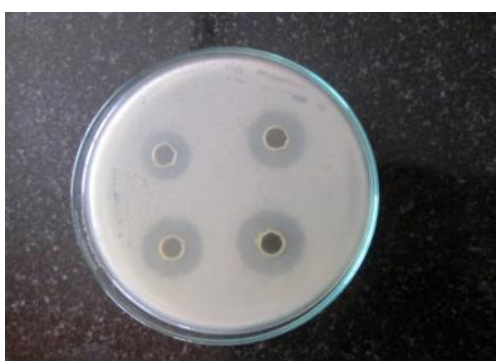

Candida albicans

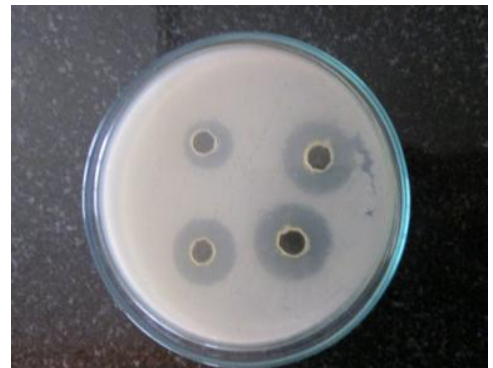

Proteus sp.,

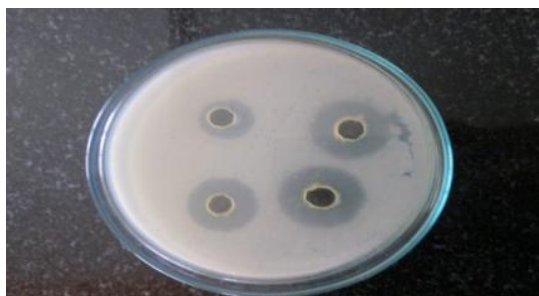

Staphylococcus aureus 
Table.5 Hyaluronidase Inhibition Assay of Phytochemicals of Gracilaria salicornia

\begin{tabular}{|c|c|}
\hline $\begin{array}{c}\text { Phytochemical } \\
\text { constituents }\end{array}$ & $\begin{array}{c}\text { Hyaluronidase } \\
\text { inhibition }(\boldsymbol{\mu g} / \mathbf{m l})\end{array}$ \\
\hline Aqueous extracts & 0.87 \\
\hline Alkaloids & 0.42 \\
\hline Flavonoids & 0.51 \\
\hline Triterpenoids & 0.63 \\
\hline Amino acids & 0.75 \\
\hline
\end{tabular}

Table.6 Effects of Gracilaria salicornia against Percentage Inhibition of Paw Edema

\begin{tabular}{lcccc}
\hline \multicolumn{5}{c}{ Paw Volume $(\mathrm{mm})$} \\
\hline Group & initial volume $(\mathrm{mm})$ & final volume $(\mathrm{mm})$ & Difference $(\mathrm{mm})$ & \% of inhibition \\
\hline Control & $4.04 \pm 0.43$ & $4.04 \pm 0.43$ & $0.00 \pm 0.00$ & - \\
Carrageenan & $4.62 \pm 0.09$ & $5.76 \pm 0.19$ & $2.27 \pm 0.14$ & - \\
Standard(10mg/kg) & $4.19 \pm 0.39$ & $4.48 \pm 0.22$ & $0.30 \pm 0.30$ & 86.86 \\
Gracillaria salicornia $(200 \mathrm{mg} / \mathrm{kg}) 5.76 \pm 0.66$ & $6.27 \pm 0.71$ & $0.51 \pm 0.07$ & 77.53 \\
\hline *values are expressed as mean \pm S.D. (n=6) p $<0.05$ & & &
\end{tabular}

Fig.2 Separation of Active Compounds y Thin Layer Chromatography

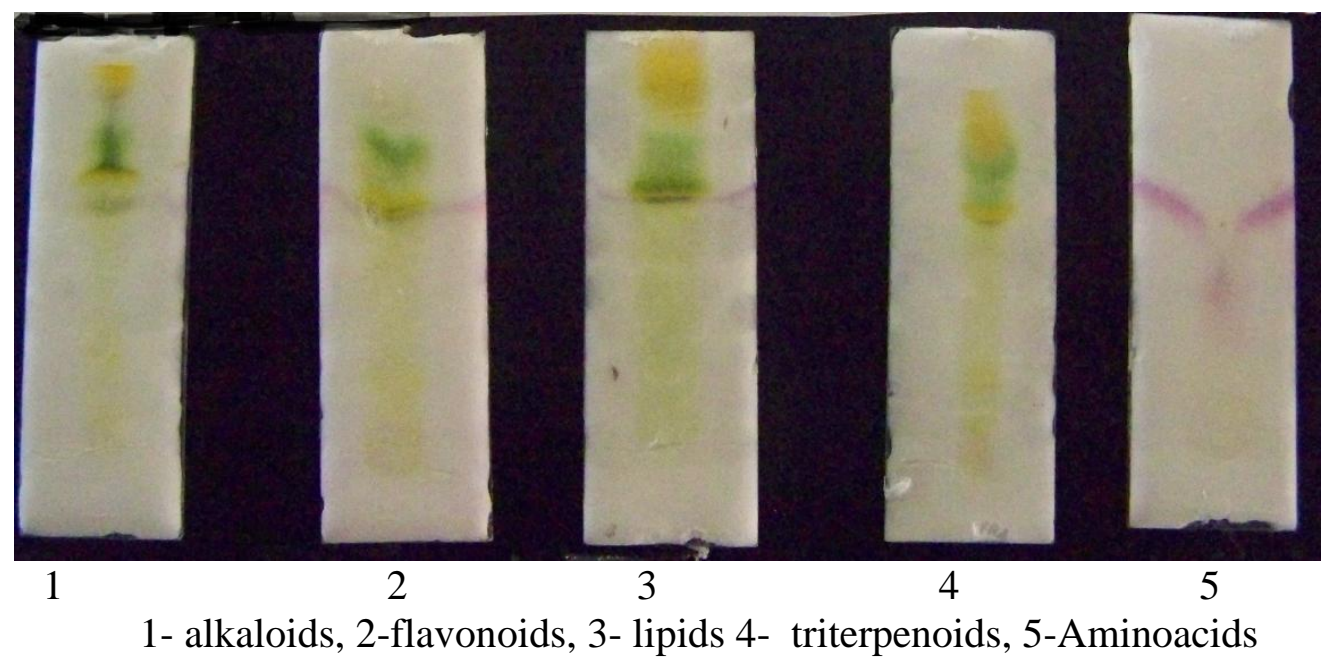

Gracilaria salicornia is red algae and they are said to be rich in sulfated polysaccharides, fucanoids and fatty acids which are commonly associated with antiinflammatory activity. Marine red algae Gracilaria salicornia displayed antiinflammatory activity in it aqueous extracts. Recent studies have examined the biological and pharmacological activities of marine algae and it was shown to be a potentially prolific source of highly bioactive secondary metabolite and could be used for the identification of novel pharmaceutical agents (Ali, 2010).

Several bioactive compounds, alkaloids, tannins, flavonoids, phenols, steroids, proteins and amino acids were present in the Gracilaria salicornia. The medicinal values of the secondary metabolites are due to the 
presence of chemical substances that produce a definite physiological action on the human body. These substances include the cell growth, replacement and body building (Kubmarawa et al., 2008).

The antibacterial activity of aqueous extracts of Gracilaria salicornia was determined against pathogens, Salmonella typhi, Bacillus, E. coli, Enterococci, Staphylococcus aureus, Proteus, Pseudomonas, Actinomycetes, Streptococcus pyogens and Candida albicans by disc diffusion method. The extracts algae exhibited significant activity against human pathogens (Bauer et al., 1966).

Thin layer chromatography techniques were carried out using respective solvents as mentioned in order to detect the presence of aqueous extracts, alkaloids, flavonoids, lipids and terpenoids. Adsorption layers TLC preparations can be standardized. Silica gel is an efficient adsorbent for the separation of algal extracts. This system select suitable the mobile phase, the stationary phase and detection method (Wagner and Bladt, 1996).

TLC profiling of algal extracts gives an impressive result that directing towards the presence of phytochemical. Various phytochemicals gives different $R f$ values in different solvent system. This variation in $R f$ values of the phytochemicals provides a very important in understanding of their polarity (Sanjay, 2013).

Hyaluronidase is an enzyme that degrades hyaluronic acid and chondroitin sulfate which are components of the extracellular matrix of connective tissue. By degrading the components of connective tissue, hyaluronidase promotes the spread of inflammatory mediators throughout these tissues, thereby contributing to the pathogenesis of inflammatory diseases such as allergic effects, migration of cancer cell, inflammation and the increase in permeability of the vascular system.

Currently, marine algae are good antiinflammatory effects in the carrageenan induced paw edema than those of standard drug (Indomethiocin). Earlier findings reported that the aqueous extract exhibited anti-microbial and anti-inflammatory activity (Radhika, 2013).

Now-a-days plant based drugs for inhibiting cancer; inflammation and glucose were emerging from different natural sources. Inflammation is a common phenomenon and it is a reaction of living tissues towards injury. For the present study in vitro and in vivo studies demonstrated an appreciable anti-inflammatory activity.

In conclusion, the aqueous extract of Gracilaria salicornia rich source of secondary metabolic compounds serves as a substitute to conventional medicines. Medicinal values of the active compounds against pathogenic organisms. It can be conclude that the extract of Gracilaria salicorniaas considered as a resource for potential anti-bacterial and antiinflammatory agents.

\section{Acknowledgement}

We acknowledge our profound gratitude to the Department of Microbiology, Nehru Arts and Science College, T.M. Palayam, Coimbatore for providing the facilities for research work. We are highly indebted to Dr. J. Rathinamala, Dr. S. Meenatchisundaram (Associate Professor) Nehru Arts and Science College, T.M. Palayam, Coimbatore for their valuable help to complete this work. 


\section{References}

Trease, G.E., Evans, W.C. 1989. Pharmacognosy. London: 13thedn. BailliereTindall, 176-180.

EskilHultin. 1966. Thin layer chromatography of plant extracts, Act a chemicascandinavica, 20: 1588-159.

Bauer, A.W., Kirby, W.M., Sherris, J.C., Turck, M. 1966 . Antibiotic susceptibility testing by a standardized single disk method. Am. J. Clinpathol., 57(9): 592-597.

Ali, A.E.G. 2010. Biological importance of marine algae. Saudi Pharma. J., 18: 125.

Nagarani, N., JanakiDevi, V., YokeshBabu, M., Kumaraguru, A.K. 2012. Protective effect of Kappaphycusalvarezii (Rhodophyta) extract against DNA damage induced by mercury chloride in marine fish. Toxicol. Environ. Chem., 94(7): 14011410.

Wagner, H., Bladt, S. 1996. Plant drug analysis-A thin layer chromatography. Atlas. Springer, 2: 1-2.

Kubmarawa, D., Khan, M.E., Punahand Hassan, A.M. 2008. Phytochemical Screening and antibacterial activity of extract

from

Pakia

Clapperotonianakeay against human pathogenic bacteria. J. Med. Pl. Res., 2: 352-355.

Anjanasharma, S., Chandraker, V.K., Patel, PadminiRamteke. 2011. Anti-bacterial activity of medicinal plants against pathogens causing complicated tract infections. Indian J. Pharma. Sci., 71: 136-139.

Sanjay, R., Birabar, Bhagyashri, D., Rachetti. 2013. Extraction of some Secondary Metabolites and Thin Layer Chromatography from different parts of Centella Asiatica L. (URB). American J. Life Sci., Vol. 1, No.6, pp. 243-247.

Radhika, D., Veerabahu, C., Priya, R. 2013. Anti-inflammatory Activities of some Seaweed Collected from the Gulf of Manner Coast, Tuticorn, South India. Int. J. Pharma and Bio Sci., 4(1): 3944.

Vasudevan, M., Gunnam, K.K., Parle, M. 2006. Anti-nociceptive and antiinflammatory properties of Daucuscarota seeds extract. J. Health Sci., 52: 598-606.

\section{How to cite this article:}

Ranganayaki Paramsivam, Susmitha Sudevan, Shalini Sundar, and Vijayaraghavan Ramasamy. 2016. Study on Metabolic Compounds of Gracilaria salicornia against Anti-Inflammatory Activity. Int.J.Curr.Microbiol.App.Sci. 5(4): 202-211. doi: http://dx.doi.org/10.20546/ijcmas.2016.504.025 